\title{
Vertical Characteristics of Reflectivity in Intense Convective Clouds using TRMM PR Data
}

\author{
Shailendra Kumar ${ }^{1}$ \\ ${ }^{1}$ IISc, India \\ Correspondence: Shailendra Kumar, IISc, India. E-mail: shailendra@caos.iisc.ernet.in, shailendrak89@gmail.com \\ Received: April 7, 2017 \\ Accepted: April 26, 2017 \\ Online Published: May 15, 2017 \\ doi:10.5539/enrr.v7n2p58 \\ URL: https://doi.org/10.5539/enrr.v7n2p58
}

\begin{abstract}
Tropical Rainfall Measuring Mission Precipitation Radar (TRMM-PR) based vertical structure in intense convective precipitation is presented here for Indian and Austral summer monsoon seasons. TRMM 2A23 data is used to identify the convective echoes in PR data. Two types of cloud cells are constructed here, namely intense convective cloud (ICC) and most intense convective cloud (MICC). ICC consists of PR radar beams having $\mathrm{Ze} \geq 40 \mathrm{dBZ}$ above $1.5 \mathrm{~km}$ in convective precipitation area, whereas MICC, consists of maximum reflectivity at each altitude in convective precipitation area, with at least one radar pixel must be higher than $40 \mathrm{dBZ}$ or more above $1.5 \mathrm{~km}$ within the selected areas. We have selected 20 locations across the tropics to see the regional differences in the vertical structure of convective clouds. One of the important findings of the present study is identical behavior in the average vertical profiles in intense convective precipitation in lower troposphere across the different areas. MICCs show the higher regional differences compared to ICCs between 5-12 km altitude. Land dominated areas show higher regional differences and Southeast south America (SESA) has the strongest vertical profile (higher Ze at higher altitude) followed by Indo-Gangetic plain (IGP), Africa, north Latin America whereas weakest vertical profile occurs over Australia. Overall SESA (41\%) and IGP (36\%) consist higher fraction of deep convective clouds $(>10 \mathrm{~km})$, whereas, among the tropical oceanic areas, Western (Eastern) equatorial Indian ocean consists higher fraction of low (high) level of convective clouds. Nearly identical average vertical profiles over the tropical oceanic areas, indicate the similarity in the development of intense convective clouds and useful while considering them in model studies.
\end{abstract}

Keywords: Convective precipitation, Precipitation vertical structure, land ocean contrast, cloud hydrometeors, TRMM PR

\section{Introduction}

Convective clouds transport the net energy gain at the surface to the upper atmosphere (Riehl \& Simpson, 1979). Radar reflectivity $(\mathrm{Ze})$ variation in the vertical structure is important as higher Ze at higher altitude indicates the convective intensity (Zipser et al., 2006; Xu \& Zipser, 2012), and vertical characteristics in convective precipitation will lead the improvement in model studies (Xu \& Zipser, 2012). In the present study, Tropical Rainfall Measuring Mission Precipitation Radar (TRMM-PR) is used to explore the vertical variation of Ze in intense convective precipitation area.

TRMM PR with other onboard TRMM sensors has been used to extract the vertical structure for precipitation. Peterson and Rutledge (2001) observed the similar precipitation vertical structure above the freezing level over the globe. Alcala and Dessler (2002) compared deep ( $\geq 10 \mathrm{~km})$ and overshooting convection $(\geq 14 \mathrm{~km})$ and observed higher convective precipitation over land areas compared to oceanic areas. Nesbitt et al. (2000; 2006) defined precipitation features (PFs) based on multiple TRMM sensors, and observed that area of PFs are higher over the land in comparison to the oceans. Liu et al. (2007) observed the large areas of cold clouds over West Pacific Ocean, whereas central Africa, Argentina, and India consist deeper and more horizontally extensive PFs, and Land dominated areas consist higher $20 \mathrm{dBZ}$ area above the freezing level (Liu et al., 2008). Liu et al. (2012) observed the relationship between lightning flash rates and vertical structure of thunderstorms. Yuan and Qie (2008) explored the south China sea before and after the onset of the summer monsoon. Qie et al. (2014) observed the deep and intense deep convective clouds over Tibetan Plateau-South Asian monsoon using $40 \mathrm{dBZ}$ crossing 10 and $14 \mathrm{~km}$ altitude respectively. Bhat and Kumar (2015) observed a close similarity in vertical profiles over land and oceanic areas in cumulonimbus towers over south Asian areas during Indian summer 
monsoon. Many TRMM observations show that Southwest Himalaya, east of the Andes in south America and West Africa consist extreme the deepest convection (Zipser et al., 2006; Houze et al., 2007; Romatschke \& Houze, 2010; Kumar \& Bhat, 2016).

Previous studies consider the $40 \mathrm{dBZ}$ at and above $10 \mathrm{~km}$ to observe the vertical structure in convective precipitation (Houze et al., 2007; Qie et al., 2014; Romatschke \& Houze, 2010; Romatschke et al., 2011a; 2011b). Previous criteria underestimate some intense clouds, which evolve near the surface, but are not very deep $(>10 \mathrm{~km})$. Their cloud top height lies into the mixed phase altitude (mid-troposphere) and even can be very shallow, and are important while considering the ice and warm rain microphysics in the model study. TRMM PR provides a unique opportunity to measure the Ze over all the tropics compared to ground based radar or aircraft, as the information of vertical profiles in intense convective clouds is not clear in different part of the tropics. The aim of the present study is to explore the vertical structure of Ze in intense convective clouds over the tropics during Indian and Austral summer monsoon at the individual length scale of convective clouds ( $\sim 5 \mathrm{~km}$, Lucas et at. 1994). We consider both land and oceanic areas. The paper is organized as follows, section 2 explain the data followed by methodology in section 3. Section 4 explain the results followed by the discussion in section 5 . Section 6 concludes the paper.

\section{Data}

TRMM PR derived radar reflectivity factor (Ze) for June-July-August-September (JJAS) and January-February-March (JFM) months are used in the present study for the year between 2001-2010. TRMM is a non-sun synchronous satellite and samples the globe 15-16 times in a day (Kummerow et al., 1998). TRMM $\mathrm{PR}$ is the first radar on board a satellite, works in $\mathrm{Ku}$ band $(13.8 \mathrm{GHz})$, and has a wavelength of $2.2 \mathrm{~cm}$. The TRMM multi-satellite precipitation analysis 3B42 rain product (Huffman et al., 2007) is used for the precipitation climatology (Figure 1) and to select the different regions to compare the Ze profiles in intense convective precipitation. Figure 2 shows an example of cloud vertical structure for an MCS over southeast south America observed from TRMM PR. Inset figure shows the line along which the vertical structure has been observed. We can see several individual deep clouds with Ze $\geq 40 \mathrm{dBZ}$ and their tops more than $10 \mathrm{~km}$, whereas overall cloud extends more than $18 \mathrm{~km}$. The horizontal size of the tall vertical structure is more than $10 \mathrm{~km}$ and is larger than the size of an updrafts core (e.g. $\sim 5 \mathrm{~km}$, Zipser \& Lutz, 1994). The echo top height lies between 10 to $18 \mathrm{~km}$ altitude even the Ze values are equal near the surface.

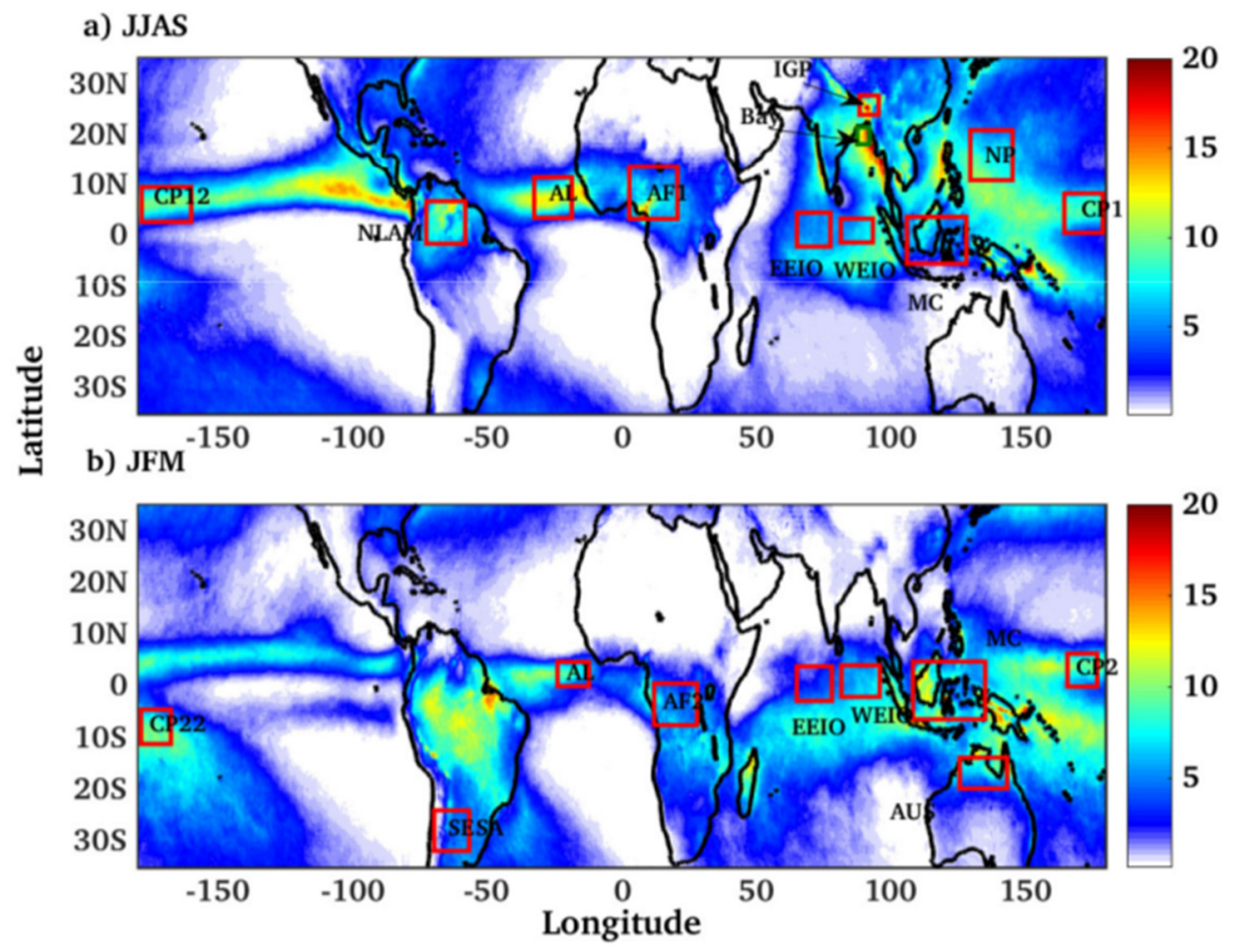

Figure 1. Daily average rainfall derived from TRMM 3B42 rainfall product for Indian summer monsoon (JJAS) seasons and Austral summer monsoon (JFM) months. Unit is in $\mathrm{mm} \mathrm{day}^{-1}$ 


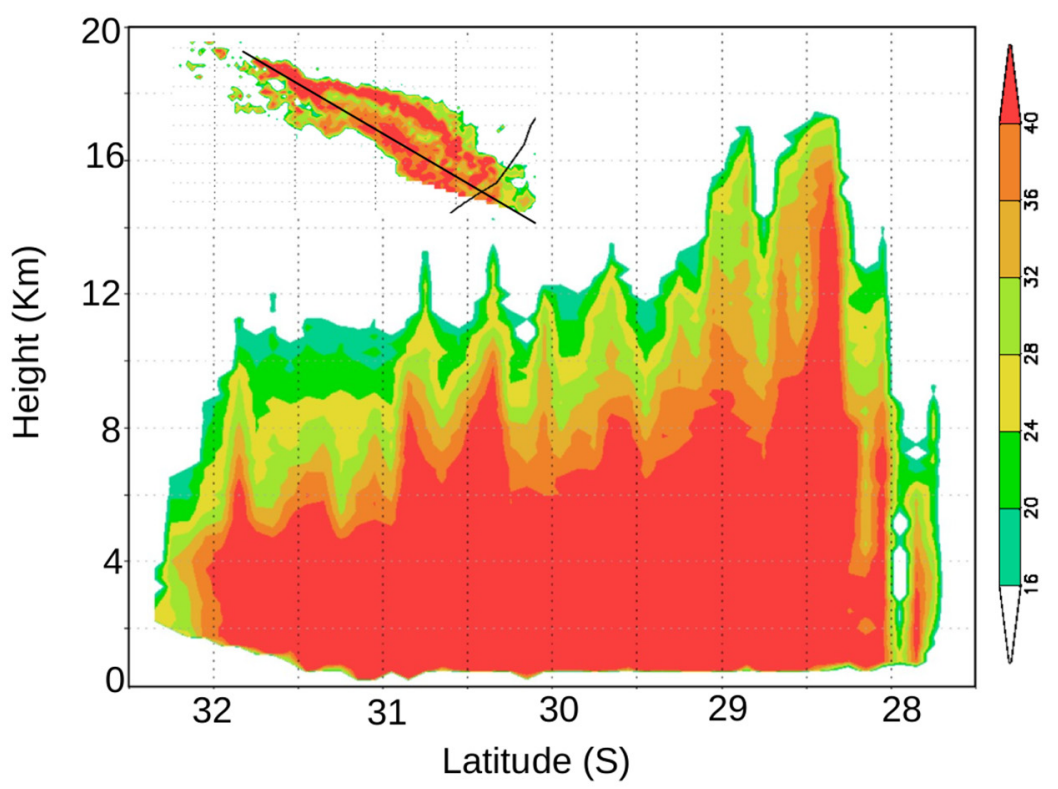

Figure 2. An example of vertical section through a MCS seen by TRMM-PR on 3rd February 2003. The inset shows horizontal section through the cloud system at $3.25 \mathrm{~km}$ height. The ordinate and abscissa are height and latitude $\left({ }^{\circ} \mathrm{S}\right)$, respectively. The colour bar on right shows Ze in dBZ unit

\section{Methodology}

To identify the convective cells enclosed in a $3 \mathrm{D}$ reflectivity field, a Ze threshold is needed at a certain height. $40 \mathrm{dBZ}$ is chosen as a reflectivity threshold based on the past studies, as in the absence of vertical velocity, the maximum altitude of $40 \mathrm{dBZ}$ can be used as a convective proxy (Zipser at al., 2006; Xu \& Zipser, 2012). Steiner et al. (1995) used $Z \mathrm{e} \geq 40 \mathrm{dBZ}$ as a proxy for a convective area in cloud systems based on ground-based radar data. In radar observation, $Z \mathrm{e} \geq 40$ and $35 \mathrm{dBZ}$ at 4.4 and $3.9 \mathrm{~km}$ respectively, were used for defining convective clouds over mid latitude and tropical systems (Zipser \& Lutz, 1994). Dixon and Wiener (1993) used the $\mathrm{Ze} \geq 40-45 \mathrm{dBZ}$ as a proxy for individual convective cells in TITAN project. Deep and wide intense convective echoes consist $Z \mathrm{e} \geq 40 \mathrm{dBZ}$ above $10 \mathrm{~km}$ altitude and are more than $1000 \mathrm{~km}^{2}$ respectively (Houze et al., 2007; Romatschke et al., 2010; Romatschke et al., 2011a; 2011b). Qie et al. (2014) used Ze $\geq 40 \mathrm{dBZ}$ above $10 \mathrm{~km}$ as a measure of intense deep convective clouds. In the recent study using TRMM PR data, Kumar $(2015 ; 2016)$ used the $40 \mathrm{dBZ}$ as a proxy for the intense convective precipitation over south Asian regions.

Two types of cloud cells are constructed here, namely intense convective cell (ICC) and most intense convective cell (MICC) based on Ze and height thresholds and briefly explained in Kumar $(2015 ; 2016)$ and here as well. First TRMM 2A23 data is used to identify the convective precipitation (Awaka et al., 2009) in each of the selected areas, and then ICC and MICC are derived. Each TRMM PR beams, which consist at least one pixel of $\mathrm{Ze} \geq 40 \mathrm{dBZ}$ above $1.5 \mathrm{~km}$ altitude within the selected areas, are considered as ICC (Kumar, 2016). A single TRMM PR pass consists several ICCs (Figure 2). Zipser and Lutz (1994) \& Xu and Zipser (2012) mentioned that, maximum Ze vertical profiles within a cloud system indicate a storm type. MICC is derived in such a way that, it consists of maximum $\mathrm{Ze}$ at each altitude from the population of convective clouds present in each PR pass, within the selected areas, with at least one convective pixels higher than $40 \mathrm{dBZ}$ above $1.5 \mathrm{~km}$ altitude (Kumar, 2015). It is important to know that all the pixels are not connected in the MICC, but most of the times they are connected (Kumar, 2015). To remove the multilayer clouds, only those vertical profiles are considered here, which consist at-least four Ze pixels higher than $17 \mathrm{dBZ}$ above the altitude, where Ze was less than $17 \mathrm{dBZ}$. Also, MICCs and ICCs with less than $1.5 \mathrm{~km}$ width are not considered in the present study, which is very shallow. 

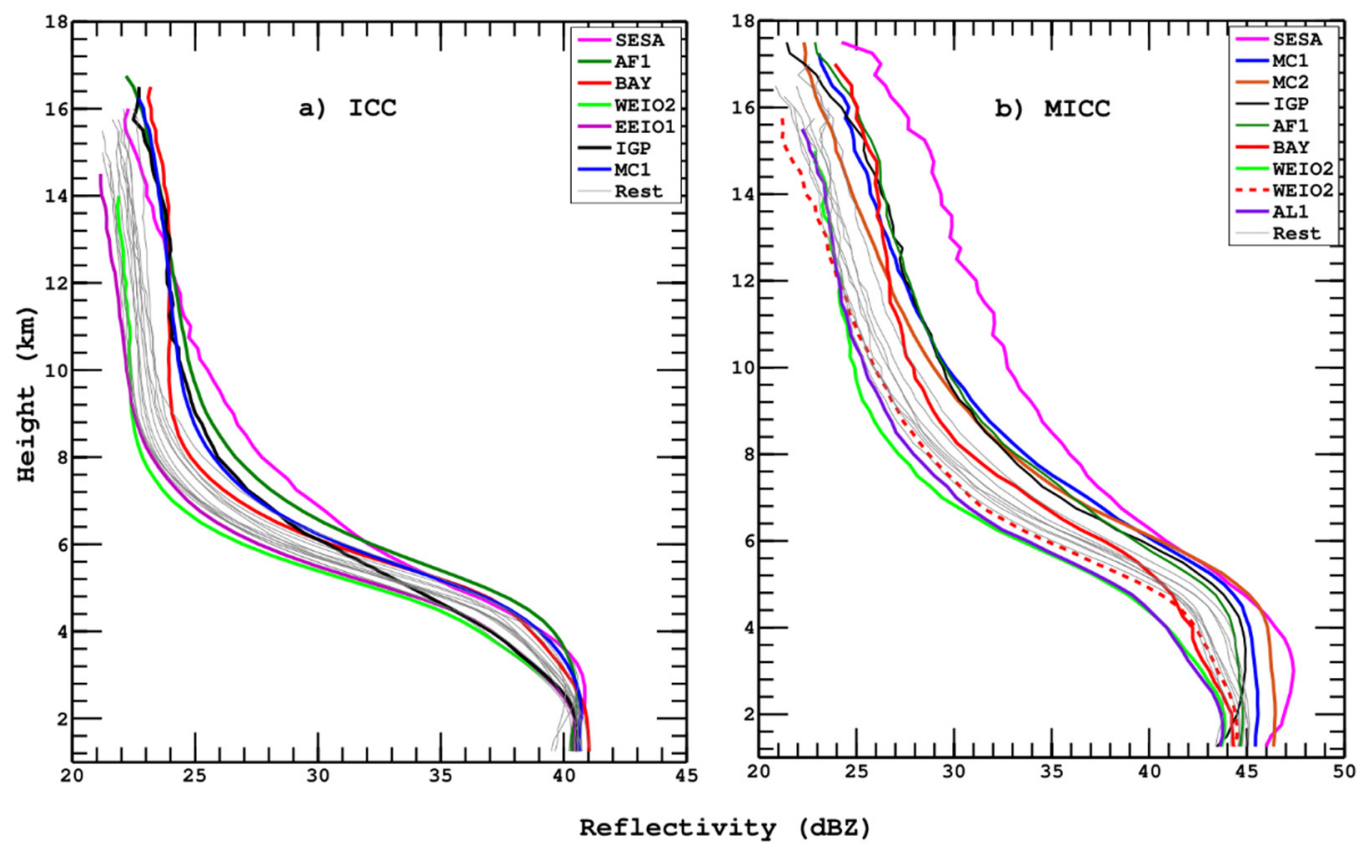

Figure 3. Average vertical profile for ICCs (a) and MICCs (b). The average is calculated by considering that $90 \%$ of data points contribute at each altitude. Data below $1.5 \mathrm{~km}$ is also removed because of ground clutter. Only extreme cases are shown by dark colour line and rest is shown by thin black line

The physical significance of MICC and ICC are mentioned below. Evolution of cloud system consists growing, mature and decaying stages. In deep and intense convective clouds, growth phase lifts the hydrometeors to the upper troposphere and when updrafts weaken, large hydrometeors start their downward journey as well as grow in size along with their journey. The early mature phase consists a Ze peak in the upper troposphere (Williams et al., 1989). Below the freezing level, Ze increases because of microphysical processes as well as phase change from ice to liquid phase (Houze, 1993; Fabry \& Zawadzki, 1995), and the peak below the freezing level may correspond to the later stage of the mature phase. So, we expect the ICC and MICC consist the cells derived from the different phases of the cloud systems.

\section{Results}

Nearly 41000 TRMM PR passes are used in the present study. Table-1 shows the number of ICCs and MICCs observed over different selected areas. Supplementary figure-1 shows the individual vertical profiles of ICCs over Bay of Bengal and Maritime Continent. Some individual vertical profiles cross the $16 \mathrm{~km}$ altitude, whereas some are very shallow and are not able to cross the freezing height $(\sim 4-5 \mathrm{~km})$.

\subsection{Selection of Different Areas}

TRMM PR data products from same instruments provide Ze around the globe for long time series (almost 17 years). Because of the large volume of data sets, we consider 20 areas (locations) based on the past studies. Figure 1 shows the precipitation climatology for JJAS and JFM months from the TRMM 3B42 daily precipitation data at $0.25^{\circ} \times 0.25^{\circ}$ resolution (Huffman et al., 2007), for 2001 to 2013 years. Selection of different areas is based on the and past studies (Figure 1). Bay of Bengal (Bay) exhibits organized convective systems (Zudima, 2003) and selected to understand the intense convective precipitation vertical structure. Convection over Eastern equatorial Indian Ocean (EEIO, $90^{\circ}-110^{\circ} \mathrm{E}, 0-10^{\circ} \mathrm{S}$ ) and Western equatorial Indian Ocean (WEIO, $50^{\circ}-70^{\circ} \mathrm{E}, 10^{\circ} \mathrm{S}-10^{\circ} \mathrm{N}$ ) is negatively and positively correlated with Indian summer monsoon rainfall (Bhat et al., 2001), and so we select the boxes over EEIO and WEIO during both the seasons. The Maritime Continent (MC) contributes significantly to the precipitation during both JJAS and JFM months (Ramage, 1968) and so the MC is selected during both seasons. Several areas are selected over Pacific and Atlantic oceans (e.g., center and north Pacific, CP1, CP2, NP and AL) to compare them with the other areas over tropical oceans. Indo-Gangetic plain (IGP) consists the highest number of cumulonimbus clouds during JJAS (Bhat \& Kumar, 2015) and selected for the study. Land dominated areas over Africa (AF), north Latin America (NLAM), southeast south America (SESA) and north Australia (AUS) are selected, which are known to produce 
the intense convective clouds (Zipser et al., 2006; Romatschke \& Houze, 2010; Zuluaga \& Houze, 2015; Kumar $\&$ Bhat, 2016). The common areas during both seasons are indicated by ' 1 ' and ' 2 ' for JJAS and JFM months respectively.

Table 1. Number of ICCs and MICCs occur in each area with the distribution of cloud top height e.g., maximum height of $20 \mathrm{dBZ}$. The fraction of ICCs, which are shallow $(<6 \mathrm{Km})$ and deep $(>10 \mathrm{Km})$ are shown here. The suffix ' $\mathrm{O}$ ' is used to indicate the ocean except for Bay

\begin{tabular}{lllll}
\hline Regions & ICC & MICC & \multicolumn{2}{c}{ MH20 for ICC $(\%)$} \\
\cline { 4 - 5 } 1. BAY-JJAS & 51098 & 1084 & 19.75 & 20.79 \\
2. EEIO1-JJAS & 74084 & 1844 & 38.1 & 8.43 \\
3. WEIO1-JJAS & 108253 & 2213 & 14.34 & 30.28 \\
4. MC1-JJAS & 179720 & 3023 & 19.1 & 23.64 \\
5. NPO-JJAS & 135313 & 2302 & 16.18 & 20.9 \\
6. CPO1-JJAS & 117578 & 2067 & 25.19 & 13.07 \\
7. CPO12-JJAS & 64147 & 1997 & 33.92 & 12.48 \\
8. ALO1-JJAS & 71325 & 1617 & 25.16 & 16.16 \\
9. EEIO2-JFM & 114041 & 2090 & 28.68 & 15.09 \\
10. WEIO2-JFM & 129979 & 2051 & 23.52 & 17.9 \\
11. MC2-JFM & 490973 & 4664 & 19.58 & 16.5 \\
12. CPO2-JFM & 243669 & 3403 & 21.14 & 17.85 \\
13. CPO22-JFM & 94429 & 2086 & 18.44 & 14.9 \\
14. ALO2-JFM & 93891 & 1719 & 32.16 & 26.7 \\
15. AF2-JJAS & 309092 & 1229 & 13.48 & 29.67 \\
16. NLAM-JJAS & 256295 & 1375 & 15.5 & 36.82 \\
17. IGP-JJAS & 118431 & 921 & 9.11 & 36.46 \\
18. AF2-JFM & 165658 & 825 & 15.19 & 41.04 \\
19. SESA-JFM & 203526 & 520 & 6.05 & 20.72 \\
20. AUS-JFM & 43175 & 542 & 16.35 & \\
\hline
\end{tabular}

\subsection{Average Characteristics of ICC and MICC}

Figure 3 shows the average vertical profile for ICCs and MICCs, and MICCs show the higher regional differences compared to ICCs. Only the extreme cases are shown by solid color lines whereas other are shown by thin black lines. Average behavior can be mainly discussed in two regions, below the $4 \mathrm{~km}$ where Ze is either increases, remain constant or decreases with altitude, and above $5 \mathrm{~km}$, where Ze decreases rapidly as the altitude increases. In both the cases, the mixed phase regions $(6-9 \mathrm{~km})$ consist the higher regional differences. Below 4 $\mathrm{km}$, ICCs show a close the similarity among different selected areas, and regional differences are less than $3 \mathrm{dBZ}$ Regional differences increase at higher altitude and $\sim 8 \mathrm{dBZ}$ differences are observed in extreme cases. SESA shows the highest Ze between 6-10 km followed by AF1, IGP, and MC1 respectively, whereas Bay of Bengal shows highest Ze above $13 \mathrm{~km}$ altitude (Figure 3a), and AUS shows the weakest vertical profile among land dominated areas (not shown). Among the tropical oceans, Bay of Bengal shows the highest Ze values above 13 $\mathrm{km}$ altitude, whereas WEIO2 and EEIO1 contribute to weakest Ze profiles, e.g. consist least Ze at all the altitudes (Figure 3a). MICCs show the higher regional differences and extreme cases show more than $10 \mathrm{dBZ}$ differences above the $6 \mathrm{~km}$ altitude, whereas $5 \mathrm{dBZ}$ differences below the $4 \mathrm{~km}$ altitude (Figure 3b). Again SESA shows the strongest vertical profile (highest Ze) followed by MC2, MC1, IGP and AF1 below the $4 \mathrm{~km}$, whereas above $6 \mathrm{~km}$ except for MC2, all the areas nearly overlap. WEIO2, WEIO1, and AL1 contribute to weakest vertical profile e.g. consist least Ze (Figure 3b). 


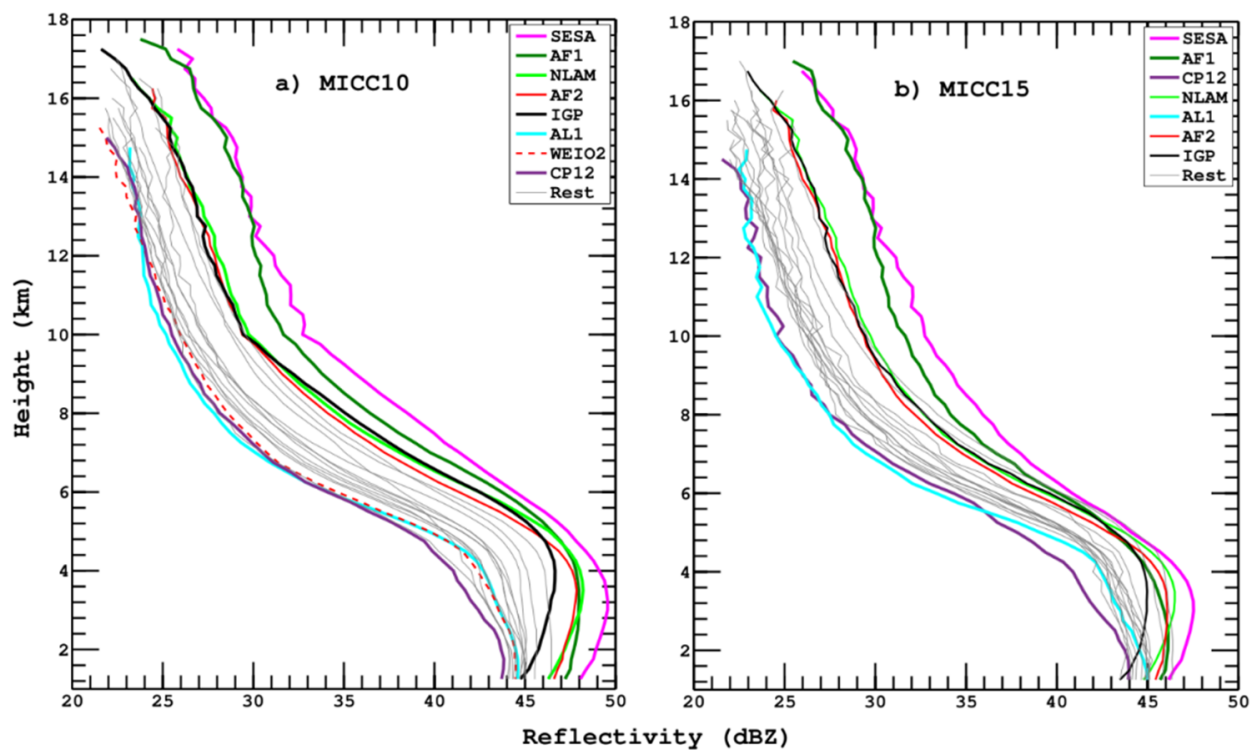

Figure 4. Average vertical profile for MICCs, which are crossing $10 \mathrm{~km}$ (a) and $15 \mathrm{~km}$ (b) respectively. The average is calculated by considering that atleast $90 \%$ of data must contribute at each altitude. Data below $1.5 \mathrm{~km}$ is also removed because of ground clutter. Only extreme cases are shown by dark colour line and rest is shown by thin black line

Figure 4 shows the average vertical profile of MICCs, which are crossing $10 \mathrm{~km}$ (MICC10) and $15 \mathrm{~km}$ (MICC15) altitude respectively. Now the land and ocean differences are more clear compared to the previous case, and again land dominated areas consist stronger vertical profile e.g., higher Ze compared to oceanic regions, and the extreme cases show more than $10 \mathrm{dBZ}$ differences. Again SESA shows higher Ze followed AF1, IGP, NLAM and AF2, and AF1 matches with SESA above $12 \mathrm{~km}$ altitude. WEIO2, CP12/2, and AL1 show the weakest vertical profile (Figure 4a). MICC15 shows the same characteristics, and SESA shows the strongest vertical profile followed by AF1, IGP, NLAM and AF2, and CP12/2 and AL1 show the weakest vertical profile. MICC10 and MICC15 show weaker gradient above the $6 \mathrm{~km}$ compared to the previous case (Figure $4 \mathrm{~b}$ ).

\subsection{Cloud Top Height Distribution}

Figure 5 shows frequency distribution of maximum height of $20 \mathrm{dBZ}$ (MH20), $30 \mathrm{dBZ}$ (MH30) and $40 \mathrm{dBZ}$ (MH40) for MICCs at $0.25 \mathrm{~km}$ interval. In each panel, extreme cases are shown by dark color lines, whereas rest cases are shown by the thin black line. MH30 and MH40 represent the proxy for convective intensity in absence of vertical velocity (Zipser et al., 2006), whereas MH20 is considered as cloud top height (CTH) in the present study. Common features are observed in all the cases, and land (ocean) areas consist the highest fraction of high (low) level of convective clouds. MH20 and MH30 consist the single mode, whereas MH40 consists two modes. Overall SESA and IGP consist higher fraction of deep convective clouds, whereas WEIO1 and CP12 consist higher fraction of low level of convective clouds.

Figure 6 shows cumulative frequency distribution for ICCs. SESA has the higher fraction of deep convective clouds followed by IGP and AF2, whereas WEIO1 and CP12 consist the higher fraction of the low level of convective clouds. More than 80\% ICCs CTH (MH20) cross the $6 \mathrm{~km}$ over SESA, whereas the corresponding altitude for WEIO1 is $4 \mathrm{~km}$ (Figure 6c) and, 50\% ICCs cross $9 \mathrm{~km}$ altitude over SESA whereas the corresponding altitude over WEIO1 is only $6 \mathrm{~km}$ (Fig 6a). Table 1 shows the detailed information about the CTH in ICCs. SESA has $41 \%$ ICCs above $10 \mathrm{~km}$ followed by IGP and AF2 (36\%) and NLAM (30\%), whereas WEIO1 has the least fraction $(9 \%)$ of ICCs above $10 \mathrm{~km}$ altitude. Among the tropical oceanic areas, EEIO1 has the highest fraction (30\%) of ICCs above $10 \mathrm{~km}$ altitude followed by MC1. WEIO1 has the $38 \%$ of ICCs having their tops, which are below $6 \mathrm{~km}$, followed CP12 (33\%) and AL2 (32\%). Within land dominated areas, AUS has highest fraction $(\sim 21 \%)$ of the low level of convective clouds followed by NLAM, and least over SESA (6\%) followed by IGP $(9 \%)$. 


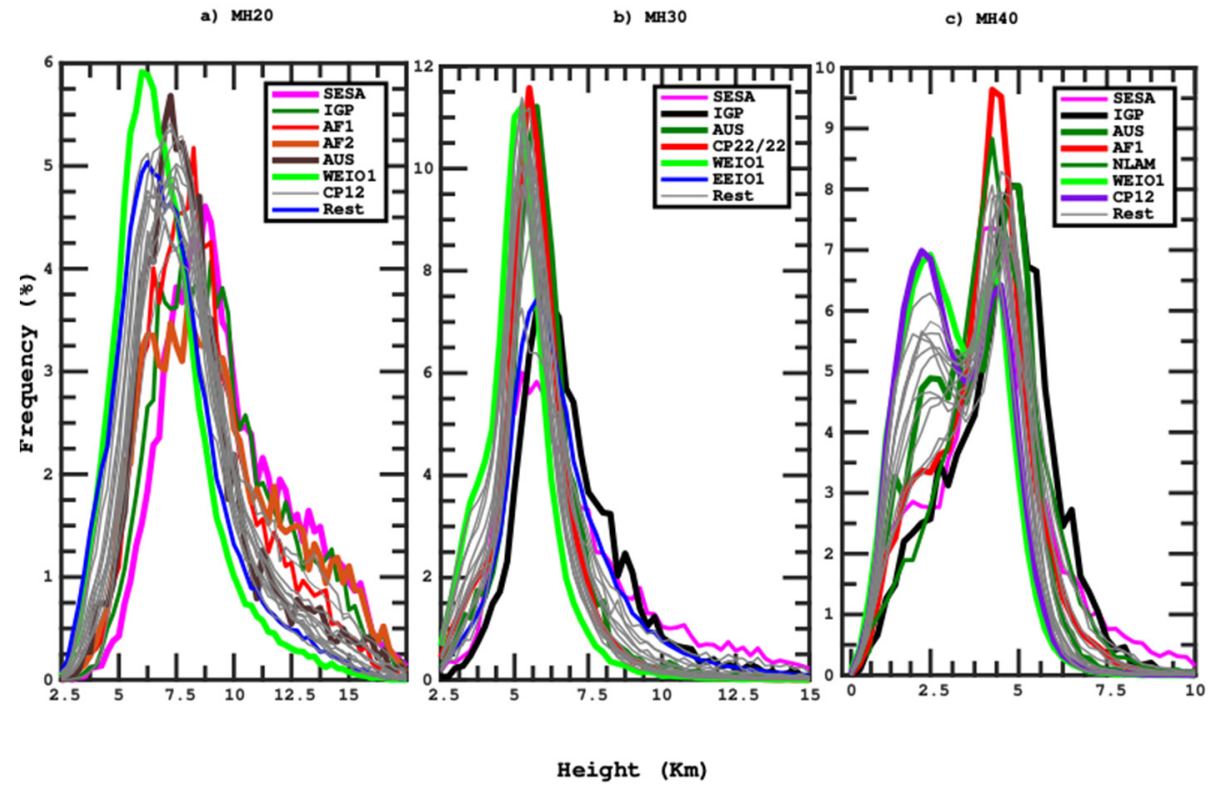

Figure 5. Frequency distribution of cloud top height (MH20) for MICC (a) MH30 (b) and MH40 (c) respectively (see the text for definition for MH20, MH30 and MH40). The $\mathrm{x}$-axis is height and the frequency is calculated at each $0.25 \mathrm{~km}$ interval. Only extreme cases are shown by dark color line and rest is shown by thin black line
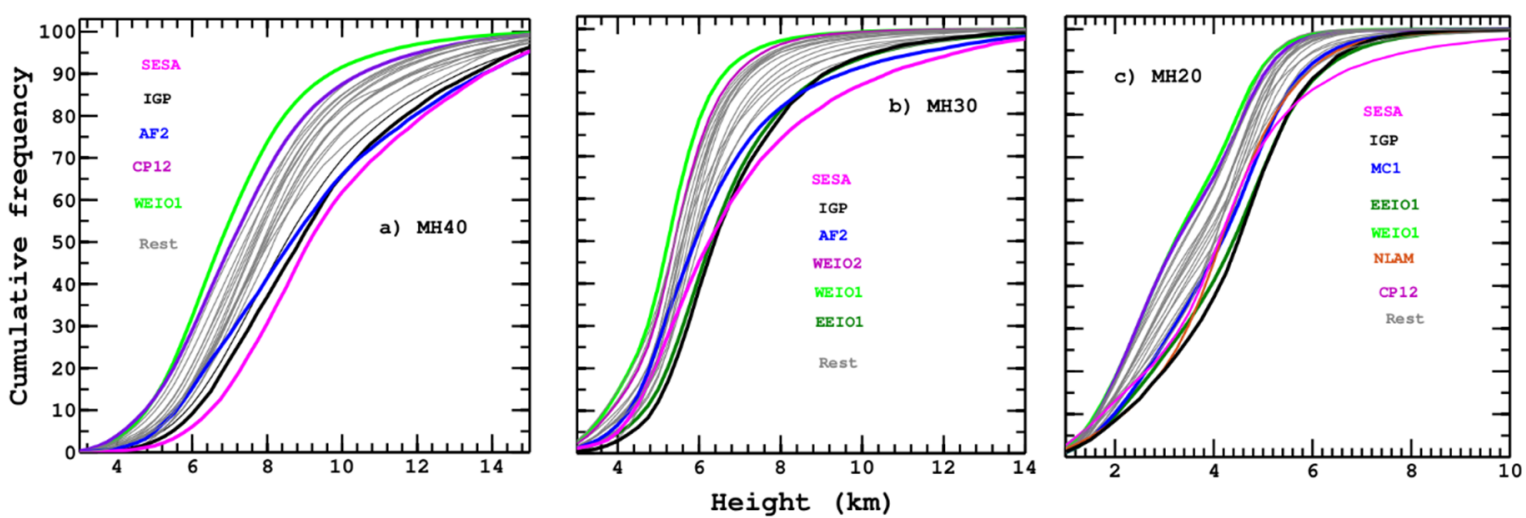

Figure 6. Cumulative frequency distribution of cloud top height distribution for ICC. The $\mathrm{x}$-axis is height and the cumulative frequency is calculated at each $0.25 \mathrm{~km}$ interval. Only extreme cases are shown and rest is shown by thin black line

\section{Discussions}

Present study explores the vertical characteristics of intense convective clouds, depicted by MICCs and ICCs. The convective cloud cells, which are treated in the present study are very intense as some of them extend deep into the upper atmosphere $(>10 \mathrm{~km})$ whereas some are very shallow $(<4 \mathrm{~km})$, but both of them exhibits Ze higher than 40-50 dBZ (Supplementary Figure 1) near the surface. A close similarity in ICCs in mid and lower troposphere indicate the similar development in ICCs across the tropical areas and can play a key role for understanding of the intense convective clouds across the tropics. The maximum average values are observed between 3 to $5 \mathrm{~km}$ altitude; and the lower value above the $10 \mathrm{~km}$ could be because of $\mathrm{Ze}$ values approaching the PR detection limit (17 dBZ; Kummerrow et al., 1998). Average behavior shows that Ze increases from their tops to freezing level and then either increase, remains constant or decreases below the freezing level, depends on areas. This corresponds to different microphysical processes occur below and above the freezing level.

Updraft speed plays an important role in determining the microphysical processes, but unavailable for the study (Liu \& Zipser, 2013; Heymsfield et al., 2010). An average vertical profile, which consists higher Ze in upper altitude, suggests the higher growth rate of hydrometeors. Due to high updraft velocity, hydrometeors consist 
very less time to grow during their growth phase and higher hydrometeors are carried to upper atmosphere (Heymsfield et al., 2010). In mixed phase regions, higher updraft velocity provides fewer time to the hydrometeors to enlarge and they get carried to higher altitudes (Fabary \& Zawadaki, 1995). During its upward journey hydrometeors grow in size, and only fall when terminal velocity exceeds the updraft speed. Weaker updraft velocity provides enough time to hydrometeors to fall down, and their size increases, as they fall within clouds (Lucas et al., 1994). When the updraft speed tends to lower in the upper troposphere, large sized hydrometeors start their downward journey and grow in size in mixed phase regions, and even when they melt, Ze shows the bright band.

The decreasing trends of Ze above the freezing level are related to phase change of water, as well as the precipitation processes, occur above and below the freezing level. Ze within the mixed phase regions depends on the size of the hydrometeors at the different altitude that too affected by the phase change i.e. hydrometeors are in lower, upper troposphere or in mixed phase regions. Ze value in $\mathrm{dBZ}$ is calculated using the complex reflective index of water which is much higher ( 4.5 times) compared to ice. Also, above the freezing level ( $\sim 5$ $\mathrm{km}$ over tropics) conversion from liquid to ice decreases the Ze by $6.5 \mathrm{dBZ}$ (Fabary \& Zawadaki, 1995). Hydrometeors grow in size within the mixed phase region due to ascending of cloud air mass, whereas larger sized hydrometeors descend and grow in size during their downward journey because $\mathrm{Ze}$ is proportional to $6^{\text {th }}$ power of the hydrometeors size (Houze, 1993). These mechanisms are more favored over the regions, where the updraft speed in mixed phase region is low such as over the oceans (Lucas et al., 1994).

All the average vertical profiles show the less Ze values as well as less slope above the $10 \mathrm{~km}$ altitude and may be TRMM PR sensitivity ( $\sim 17 \mathrm{dBZ})$ at these levels plays a vital role. TRMM PR samples the cloudy pixels as a function of altitude (Figure 3 from Bhat and Kumar 2015; Figure 6 from Kumar and Bhat 2016). Also a very close look at supplementary Figure 1 shows that almost all the ICC clouds extend up to $4-5 \mathrm{~km}$ and then their number decreases rapidly with height above $6 \mathrm{~km}$ altitude. Over the tropical oceanic areas due to the precipitation fallout above the freezing level, hydrometeor concentration becomes too less for the PR echo strength. Because of this sampling issue the actual cloud top height could be few km higher at upper altitude as well as the number of ICCs and MICCs could be higher at upper altitude. If sampling does not affect the results then less slope and value at upper levels due to less concentration, low growth rate and size of the hydrometeor.

\section{Conclusions}

The main conclusions of the present study as follows:

1) Different tropical oceanic areas consist similar average vertical structure. Land dominated areas have higher regional variability and the differences in the vertical profile are higher in mixed phase regions. Radar reflectivity decreases more rapidly above $5 \mathrm{~km}$ over the oceanic areas compared to land dominated areas.

2) Reflectivity decreases toward the surface below $4 \mathrm{~km}$ for ICC and MICC over both land and ocean. Land versus ocean separation is visible in most intense convective clouds and even higher, when it crosses $10 \mathrm{~km}$ altitude.

3). On an average, clouds over the south-east south America are more intense (shows higher reflectivity values) and Australia has the weakest vertical profile among the land dominated areas. Other land dominated areas lie between them and their intensity depends on the cloud top height. Within the tropical oceanic areas, Bay of Bengal shows the most intense convective clouds, whereas western equatorial Indian ocean and Atlantic ocean show the weakest vertical profile in ICC.

4). Cloud top height shows the single mode irrespective of areas. Within the tropical oceans, western equatorial Indian ocean consists highest (least) fraction of cloud tops below (above) $6 \mathrm{~km} \mathrm{(10)} \mathrm{km} \mathrm{respectively,} \mathrm{whereas}$ eastern equatorial Indian oceans consist the highest fraction of clouds more than $10 \mathrm{~km}$ altitude. Among the land dominated areas south-east south America and Indo-Gangetic plain consist more deep clouds whereas Australia has higher shallower clouds.

\section{References}

Alcala, C. M., \& Dessler, A. E. (2002). Observations of deep convection in the tropics using the Tropical Rainfall Measuring Mission (TRMM) precipitation radar. Journal of Geophysical Research: Atmospheres, 107(D24). https://doi.org/10.1029/ 2002JD002457

Awaka, J., Iguchi, T., \& Okamoto, K. I. (2009). TRMM PR standard algorithm 2A23 and its performance on bright band detection. Journal of the Meteorological Society of Japan. Ser. II, 87, 31-52. 
Bhat, G. S., \& Kumar, S. (2015). Vertical structure of cumulonimbus towers and intense convective clouds over the South Asian region during the summer monsoon season. Journal of Geophysical Research: Atmospheres, 120(5), 1710-1722. https://doi.org/10.1002/ 2014JD022552

Bhat, G. S., Gadgil, S., Kumar, P. H., Kalsi, S. R., Madhusoodanan, P., Murty, V. S. N., ... \& Ravichandran, M. (2001). BOBMEX: The Bay of Bengal monsoon experiment. Bulletin of the American Meteorological Society, 82(10), 2217-2243.

Dixon, M., \& Wiener, G. (1993). TITAN: Thunderstorm identification, tracking, analysis, and nowcasting-A radar-based methodology. Journal of Atmospheric and Oceanic Technology, 10(6), 785-797.

Fabry, F., \& Zawadzki, I. (1995). Long-term radar observations of the melting layer of precipitation and their interpretation. Journal of the atmospheric sciences, 52(7), 838-851.

Heymsfield, G. M., Tian, L., Heymsfield, A. J., Li, L., \& Guimond, S. (2010). Characteristics of deep tropical and subtropical convection from nadir-viewing high-altitude airborne Doppler radar. Journal of the Atmospheric Sciences, 67(2), 285-308.

Houze, R. A. (1993). Cloud Dynamics. San Diego, Calif: Academic Press Inc.

Houze, R. A., Wilton, D. C., \& Smull, B. F. (2007). Monsoon convection in the Himalayan region as seen by the TRMM Precipitation Radar. Quarterly Journal of the Royal Meteorological Society, 133(627), 1389-1411.

Huffman, G. J., Bolvin, D. T., Nelkin, E. J., Wolff, D. B., Adler, R. F., Gu, G., ... \& Stocker, E. F. (2007). The TRMM multisatellite precipitation analysis (TMPA): Quasi-global, multiyear, combined-sensor precipitation estimates at fine scales. Journal of Hydrometeorology, 8(1), 38-55.

Kumar, S. (2016). Three dimensional characteristics of precipitating cloud systems observed during Indian summer monsoon. Advances in Space Research, 58(6), 1017-1032.

Kumar, S. (2015). A 10-year climatology of vertical properties of most active convective clouds over the Indian regions using TRMM PR. Theoretical and Applied Climatology, 127(1-2), 429-440. https://doi.org/10.1007/ s00704-015-1641-5

Kumar, S., \& Bhat, G. S. (2016). Vertical profiles of radar reflectivity factor in intense convective clouds in the tropics. J Appl Met Climatol, 55(5), 1277-1286.

Kummerow, C., Barnes, W., Kozu, T., Shiue, J., \& Simpson, J. (1998). The tropical rainfall measuring mission (TRMM) sensor package. J Atmos Oceanic Tech, 15, 809-817

Liu, C., \& Zipser, E. J. (2013). Why does radar reflectivity tend to increase downward toward the ocean surface, but decrease downward toward the land surface?, J Geophys Res Atmos, 118, 135-148, https://doi.org/101029/2012JD018134

Liu, C., Cecil, D. J., Zipser, E. J., Kronfeld, K., \& Robertson, R. (2012). Relationships between lightning flash rates and radar reflectivity vertical structures in thunderstorms over the tropics and subtropics. $J$ Geophys Res, 117, D06212. https://doi.org/10.1029/2011JD017123

Liu, C., Zipser, E. D., \& Nesbitt, S. W. (2007). Global distribution of tropical deep convection: different perspectives from TRMM infrared and radar data. J Climate, 20, 489-503

Liu, C., Zipser, E. D., Cecil, S. W., Nesbitt, S. W., \& Sherwood, S. (2008). A cloud and precipitation feature database from nine years of TRMM observations. J Appl Meteorol Climatol, 47(10), 2712-2728

Lucas, C., Zipser, E. J., \& LeMone, M. A. (1994). Vertical velocity in oceanic convection off tropical Australia. $J$ Atmos Sci, 51, 3183-3193

Nesbitt, S. W., Cifelli, R., \& Rutledge, A. (2006). Storm morphology and rainfall characteristics of TRMM precipitation features. Mon Weather Rev, 134, 2702-2721

Nesbitt, S. W., Zipser, E., \& Cecil, C. (2000). A census of precipitation features in the tropics using TRMM radar, ice scattering, and lightning observations. J Climate, 13, 4087-4106

Petersen, W. A., \& Rutledge, S. A. (2001). Regional variability in tropical convection: Observation from TRMM. J. Clim., 13, 4087-4106.

Qie, X. S., Wu, X. K., Yuan, T., Bian, J. C., \& Lu, D. R. (2014). Comprehensive pattern of deep convective systems over the Tibetan Plateau-South Asian monsoon region based on TRMM data. J Clim, 27, 66126626. https://doi.org/10.1175/JCLI-D-14-00076.1. 
Ramage, C. S. (1968). Role of a tropical 'Maritime Continent' in the atmosphere circulation. Mon Wea Rev, 96. 365-370

Riehl, H., \& Simpson, J. S. (1979). The heat balance in the equatorial trough zone, revisited, Contrib. Atmos Phy, $52,287-305$

Romatschke, U., \& Houze, R. A. Jr (2011a). Characteristics of precipitating convective systems in the premonsoon season of South Asia. J Hydrometeorol, 12, 3-26. https://doi.org/10.1175/2010JHM1289

Romatschke, U., \& Houze, R. A. Jr (2011b). Characteristics of precipitating convective systems in the South Asian Monsoon. J Hydrometeorol, 12, 157-180. https://doi.org/10.1175/2010JHM1311.1

Romatschke, U., Medina, S., \& Houze, R. A. Jr (2010). Regional, seasonal, and diurnal variations of extreme convection in South Asian region. J Climate, 23, 419-439

Steiner, M., Houze, R. A., \& Yuter, S. E. (1995). Climatological characterization of three-dimensional storm structure from operational radar and rain gauge data. J Appl Meteorol, 34, 1978-2007

Williams, E. R., Weber, M. E., \& Orville, R. E. (1989). The relationship between lighting type and convective state of thunderstorms. J Geophys Res, 94, 13213-13220

$\mathrm{Xu}$, W., \& Zipser, E. J. (2012). Properties of deep convection in tropical conti- nental, monsoon, and oceanic rainfall regimes. Geophys Res Lett, 39. https://doi.org/10.1029/2012GL051242

Yuan, T., \& Qie, X. (2008). Study on lightning activity and precipitation characteristics before and after the onset of the South China Sea summer monsoon. J Geophys Res, 113, D14101. https://doi.org/10.1029/2007JD009382.

Zipser, E. J., \& Lutz, K. (1994). The vertical profile of radar reflectivity of convective cells a strong indicator of storm intensity and lightning probability. Mon Weather Rev, 122, 1751-1759.

Zipser, E. J., Cecil, D. J., Liu, C., Nesbitt, S. W., \& Yorty, D. P. (2006). Where are the most intense thunderstorms on Earth? Bull Am Meteorol Soc, 87, 1057-1071.

Zuidema, P. (2003). Convective Clouds over the Bay of Bengal. Mon Wea Rev, 131, 780-798.

Zuluaga, M. D., \& Houze, R. A. Jr (2015). Extreme convection of the near equatorial Americas, and adjoining oceans as seen by TRMM. Mon Wea Rev, 143, 298-316.

\section{Appendix}
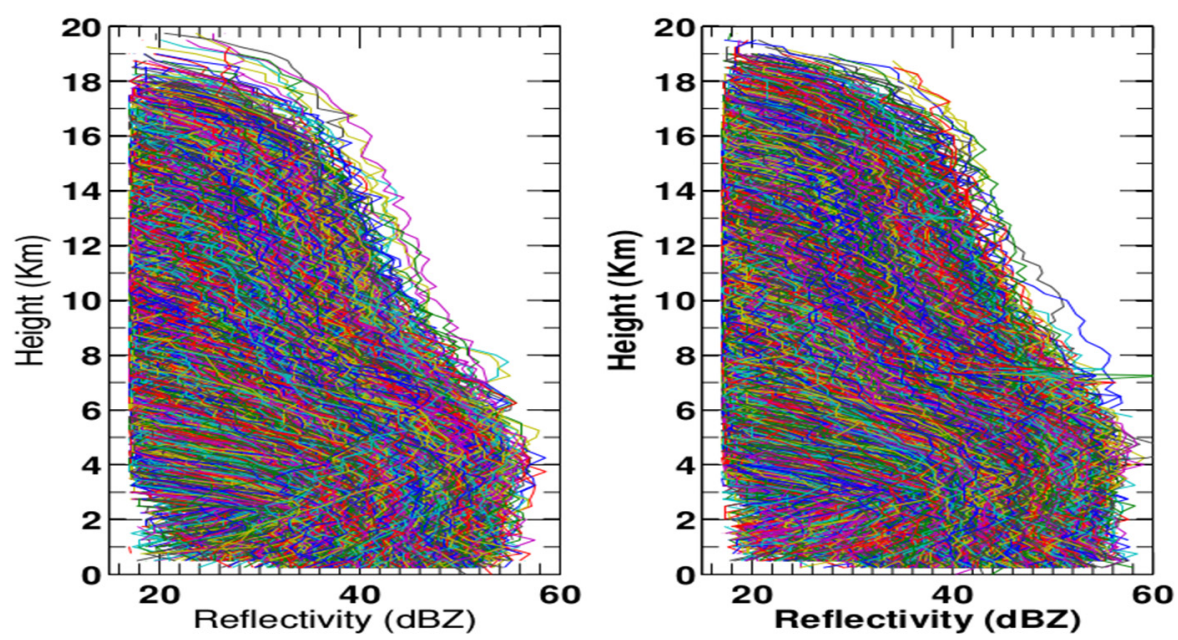

Supplementary Figure 1. Individual vertical profile for intense cloud cells for Bay and Maritime Continent

\section{Copyrights}

Copyright for this article is retained by the author(s), with first publication rights granted to the journal.

This is an open-access article distributed under the terms and conditions of the Creative Commons Attribution license (http://creativecommons.org/licenses/by/4.0/). 